\title{
'I want to buy my own block of land' Representation of urban settlement communities in Papua New Guinea
}

\begin{abstract}
Urban settlements are home to around half the urban population of Papua New Guinea. Since the end of the Second World War, PNG towns and cities have experienced significant growth of urban settlements. Urban dwellings were established on customary and untransformed state lands. With limited support for services from government, informal settlements in the urban landscape have often been perceived from the perspective of their deficiencies. However, residents of urban settlement communities play an important role in urban economies. The purpose of this article is to critically review perceptions of settlements and issues affecting settlement communities in PNG, both in the mainstream media and from within settlement communities. The authors first present a media content analysis of reporting on settlement communities on PNG's main online media sites. Second, they examine urban market vendors' personal experiences of the challenges and solutions of living in Kamkumung Settlement in Lae. Drawing on storytelling and photovoice workshops with market vendors at Awagasi market, they argue for the need for media actively to include the voices of settlement residents. The article suggests that, by better understanding the context and personal experience of residents, journalists and the media could make a stronger contribution to sustainable development and urban planning in PNG.
\end{abstract}

Keywords: content analysis, journalism, market vendors, media representation, news media, Papua New Guinea, photovoice, storytelling, urban settlement

\author{
WILMA MOLUS \\ Queensland University of Technology \\ VERENA THOMAS \\ Queensland University of Technology \\ JACKIE KAULI \\ Queensland University of Technology \\ LAURIE BUYS \\ University of Queensland
}




\section{Introduction}

N A letter to the editor of the daily National newspaper in Papua New Guinea, published on 26 April 2021, a reader identifying herself as 'Jennifer' made a scathing critique of settlements in Port Moresby (Get rid of settlements, 2021b). The letter described people who live in settlements as 'land grabbers', and settlements themselves as 'a breeding ground for criminals who create havoc for law-abiding citizens'. Jennifer went further with overt generalisation, describing residents of the settlements as '...making money under the pretext of being poor'. To provide safety and stability in the country, and in particular Port Moresby, Jennifer appealed to the Prime Minister and the governors of all provinces in PNG to pass a law '...to eradicate and prevent settlements from existence in the country'.

Another article in the same newspaper, published on 4 March 2021 (Cops: Remove settlements, 2021a), described how Assistant Police Commissioner Anthony Wagambie Jr 'urged the government to get rid of squatter settlements where people cannot peacefully live together, and to also stop them from living in ethnic groups'. The Assistant Commissioner commented on a prolonged spate of ethnic clashes at the Vadavada settlement in Port Moresby. the country's other major daily newspaper, the PNG Post-Courier, also ran coverage of the same ethnic clashes, headlining the reporting, 'One dead, several homes torched after ethnic clash erupts in City settlements' (One dead, several homes torched, 2021). Jennifer's letter to the editor, the editor's choice of heading under which to publish it, and the subsequent articles, highlight kinds of perspectives that commonly inform the way settlements are described and reported on in PNG. In these reports, we do not get a sense of the situation of residents of settlement communities, or of their perspectives on the challenges that were reported.

The discussion around the representation of settlement communities is not a new one. Settlements have been seen and described as hubs of criminal activity lacking law-and-order, and perceptions have been linked to 'unemployment, extreme poverty and crime, characterising settlement populations as maladjusted and undesirable in the urban society' (Goddard, 2001, p. 3). With histories rooted in migration, uncertain access to land, and limited government services, settlements have occupied a challenging space in the urban landscape. In many cases, resident families have resided on a block of land for several generations, and yet are still considered to be living in an 'informal' settlement. The urban population living in settlements in the PNG cities of Port Moresby, Lae and Goroka ranges from 40 to 60 percent (World Bank World Bank Group, 2014). Dominant narratives about settlements frequently focus on the perceived deficits of the settlements, rather than their contributions to society. However, numerous upgrading initiatives are in place that aim to address structural issues within settlements. Moreover, since they comprise around half of the total population 
of PNG's cities, settlement residents play an important role in the country's urban economies.

The purpose of this article is to critically review perceptions of settlements and issues affecting settlement communities in PNG, both in the mainstream media and from within settlement communities. We first review media perspectives on urban settlement in PNG through a media content analysis of online publications of four PNG news outlets. Second, we present findings from a storytelling and photovoice project with urban residents of Kamkumung settlement, an urban settlement in Ahi Local Level Government (LLG) in Lae City. Participants of our workshop were market vendors from Awagasi market at Kamkumung, who shared personal experiences around challenges and solutions within their community. In our discussion, we examine representations of settlement communities by the media alongside, and in contrast to, the stories of settlement residents themselves. We draw conclusions regarding the potential of media to further integrate residents' perspectives, so as to challenge common misconceptions of settlement communities and more actively contribute to sustainable urban development.

\section{Background}

The emergence of informal settlements in PNG was first seen in the immediate aftermath of World War Two, beginning with the appearance of the first settlement in Port Moresby in 1945 (Numbasa \& Koczberski, 2012). However, under the colonial government, migration to urban centres was regulated, with migration policy aiming to limit the movement of indigenous inhabitants into urban areas (Mecartney \& Connell, 2017). Such anti-urbanism and restrictions on urban permanent residency (Koczberski, Curry, \& Connell, 2001) were not sustainable, however, and could not sufficiently limit movement or the growth of settlements. While both the geographical dimensions and discourses around settlements have since evolved, these colonial sentiments, and the language around rural and urban categorisations, continue to be present today.

After PNG became independent on 16 September 1975, socio-economic valueadding mechanisms from Australia were introduced in order to 'prepare' PNG for statehood. One cruicial initiative was the introduction of PNG's industrialisation programme. Industrialisation processes led to small but consistent social and economic development trends, including increased urbanisation. This urbanisation saw people who lived in villages and engaged in agricultural activities migrate to urban centres and converge into groups, forming informal settlements. Formation of settlements become a common consequence of the urbanisation process (Jones, 2012). In PNG today, this has resulted in a variety of different forms of land tenure, including settlements located on lands officially aquired from customary landowners, 'illegal' settlement on state lands, and settlements established on vacant land 
purchased or rented from customary landowners. As a result, there are differences in the structures of urban settlement communities across PNG, and these feature various standards of living, from makeshift homes, to semi-permanent and permanent houses, that are home to the growing urban population.

In the last three decades PNG has seen a stark increase in urban population and informal settlements. According to the World Bank Group (2014), 50 percent of the urban population of Port Moresby and Lae live in settlements, 40-50 percent of town population of Wewak reside in settlements, and in Goroka, 60 percent of the town population call settlements their homes. Due to lack of formal opportunities such as housing and employment, many people move and reside in unplanned settlements at the peripheries of the city (Koczberski \& Curry, 2005). Housing prices in urban areas in PNG have become unaffordable to many, including people in employment who are not provided with accommodation subsidies. The housing sector has been described as 'in crisis', with people continuing to expand living spaces for themselves (see Jones, 2012). The expansion of unplanned settlements presents challenges to urban designers and settlers. To people like Jennifer, such settlements represent an eye sore and a menace, and a source of disruption to city centres. The lack of physical and spatial planning of urban informal settlements has contributed to problematic narratives around informal settlements from outsiders.

There are many challenges that settlers face; yet, as Godard (2001) points out, settlements are not a new phenomenon, but evolving fixtures of urban settings, wherein social and economic struggles 'must be understood in the context of [the settlements'] own unique history' (p. 24). Goddard argues that settlement communities should not to be viewed via simplistic dichotomies (p. 20), and that the homogenising of settlements reduces the contributions that those living within them might make. Goddard encourages the reader to understand that the social and economic struggles of settlements 'are not unemployment but the lack of services like piped water, proper access roads, and sanitation' (p. 20). Settlements grew out a dire need for adequate and affordable housing in the urban centres, and the categorical demonising of settlement remains unconstructive. The negative portrayal of settlement from the colonial era onwards does not appropriately capture the lived experiences of settlements in PNG.

The challenges that settlements and settlers had to overcome led to the development of local strategies to create opportunities to address urban problems. Over the years, key agencies (World Bank Group, 2014) and researchers (Goddard, 2001; Kopel, Hukula, Kutan, \& Iwong, 2017; Rooney, 2019; World Bank Group, 2014) have written about the resilience, innovation and economic contributions of settlements. They encourage understanding of the social and cultural complexities of settlement communities, and argue for a deeper look at social and structural policies. 
The media play an important role in reporting on various communities and the issues pertaining to them. The media industry in Papua New Guinea is one of the most vibrant in the South Pacific region, and has experienced pronounced growth in recent times, including embracing different media and communication platforms and digital technologies (Tacchi, Horst, Papoutsaki, Thomas \& Eggins, 2013). Media platforms include print media, television, radio and online media. PNG has two main daily newspapers that are published in English, and both publish a print and an online version: The National and PNG Post-Courier. The National Broadcasting Corporation provides public radio and television. There are also private and foreign-owned radio and television providers, including the television stations EMTV and TV-WAN. While social media consumption has significantly increased in PNG over the past decade, newspapers remain the most trusted source of information in PNG (PNG citizen perceptions, 2019).

In recent years, the media have been reporting on settlements in PNG and the various events and the initiatives developed by different people to address issues in settlements. Media can directly influence perceptions about key populations. In our study, we have therefore taken a critical look at the media representation of settlements. Our media analysis and our study involving storytelling and photovoice workshops inform different ways to develop advocacy strategies to support fair representation of settlement communities.

\section{Methods}

The study employed mixed research methods, including media content analysis and participatory workshops using storytelling and photovoice. In the first research phase, the media content analysis used online newspaper articles from four news sites in PNG: The National, PNG Post-Courier, EMTV and PNG Loop. The media analysis investigated how settlement communities are represented in the media when specifically mentioned. The search term 'settlement' was used, and articles identified over 2 years from May 2019 to April 2021. Articles that related to meanings of settlement other than the physical location (for example, 'court settlement') were excluded from the analysis. Overall, a total of 72 online newspaper articles were used in the media content analysis (The National 45, PNG Post-Courier 18, EMTV 4, PNG Loop 5). The articles were analysed in terms of the content in relation to the term 'settlement', and categorised by events, commentaries, initiatives and letters. The content of the newspaper articles was then analysed, with a particular focus on the sources quoted and the choice of words used in association with settlements in PNG. The analysis provided an understanding of how informal settlements are represented in print/online media in PNG.

In the second phase of the research, storytelling and photovoice workshops were conducted with market vendors at Awagasi market in Lae, to understand 
how they, as settlement residents, would represent themselves and what they wanted their own stories to focus on. Photovoice research is a participatory visual research method that engages participants to document their own experiences (Wang, Yi, Tao, \& Carovano, 1998). The photovoice research method followed a procedural approach to data collection. Firstly, the participants shared their personal stories about Awagasi market. Secondly, cameras were given to them to capture images to support their realities of conducting market sales. Thirdly, participants collectively reflected on the photographs. Finally, a discussion of photographs was conducted within a focus group of five with other participants. The storytelling sessions were audio recorded and translated into texts, which in turn were analysed thematically to reveal layers of meanings of lived experiences. Recordings were done in Tok Pisin and later translated into English.

The photovoice method was used with ten participants, five males and five females. All of them were market vendors at Awagasi market. The participants were recruited for the research based on their residence at Kamkumung for more than five years while originally hailing from different parts of PNG. A relational research approach was used to guide the photovoice research, to ensure respect was accorded to each participant. The participants' complex experiences shared through their stories align with the oral culture in PNG. Importantly, this process enabled ten storytellers and photographers from different socio-economic and cultural backgrounds to interpret their experiences and reflect on existing issues (Musoke, Ekirapa-Kiracho, Ndejjo, \& George, 2015). The storytelling and photo voice participants were asked about their views about Awagasi market, their challenges with the market, and how they dealt with the market challenges.

The photovoice research facilitated interactive, cohesive and direct communication that supported reflections among the participants about their individual life stories and their community. These stories were then reviewed in relation to the media content analysis, to compare representation in the media with that from settlement residents. While we acknowledge that methods of analysis for each set of data were different, the open approach to capture narratives from residents was chosen to privilege and represent their voices directly.

\section{Media content analysis}

A media content analysis was conducted to understand how settlements are represented in some of the key media outlets in PNG. This analysis was based on using the search term 'settlement' in online media searches. While a comprehensive analysis of media representation across all formats and media outlets was outside the scope of our study, the analysis presented in this section provides an indication of how media engage with topics about settlements in PNG. The analysis reviewed a total of 72 articles published between May 2019 and April 2021. The National newspaper featured most of the reporting on the 
representation of settlements during this period (45 articles). The articles were categorised into events (14), initiatives (26), commentaries (17) and letters (15). In our analysis, we focused on the content under each of these categories, on the sources quoted, and on the language used.

Events were predominantly related to crimes in settlements, as well as evictions and a disease outbreak. Evictions were conducted by provincial authorities to remove illegal settlements (City authorities clamp down, 2020a), with one reporting the eviction of Nagada settlement as having no issues and proceeding well (Nagada settlement eviction begins, 2021c). In one report, the police removed makeshift houses built by young people abusing alcohol and drugs (Police destroyed makeshift houses, 2020b). Other houses in the settlements remained intact. The report noted the underlying ethnic tensions that emerged as a result of petty theft. Ethnic tensions also emerged within other settlements in Moresby. Violence in the area was reported to have been curbed, with the Assistant Police Commissioner Anthony Wagambie Jr reminding the community to refrain from inciting further issues. Reports mostly contained facts and accounts of events, and the language used to describe settlements was neutral. It was also noted that, in almost half of the articles considered, police were the main or only source of information.

Initiatives took the form of improved infrastructure, including water supply, power supply and training workshops, and initiatives to address violence and alcohol consumption. Articles reported on what government, service providers and businessmen contributed to initiatives in settlements. One such example was 'Hearty meals for days at Siraka settlement' (Nao, 2020) which profiled the MP from Kairuku Hiri providing food to the local community. There was limited inclusion of community voices in the reports - for example, in reports on a blanket ban on alcohol (Moresby South MP moves to ban alcohol, 2020), the introduction of malaria kits (Kep, 2019), and another significant initiative called the Settlement to Suburb initiative led by National Capital District (NCD) Governor Powes Pakop (Saraga settlement, 2021). In all cases, MPs highlighted how tax funds were spent in socially-valuable ways, such as supporting settlements with water and sanitation projects. These articles mainly featured the politicians and the 'good' they were doing in the community. With regards to police initiatives, articles discussed how officers were deployed into settlement areas to diffuse growing tensions. Police were quoted appealing to the government to address the social and structural issues in settlements.

In all articles about initiatives, we found no community voices to indicate how communities felt about the initiatives, with the exception of one article. In this article, resident Peter Pikes commented on the installation of water in his community, 'We face problems when it comes to water and people make fun of us. For 6-7 months we struggled to find water.' (Keneqa, 2020). In the same 
article, the member for Moresby South Tkatchenko shared similar sentiments to Pikes: 'People need water, no matter where they live. Don't brand our people because they live in settlements.' It was the only article that conveyed empathy for the community and included a community leader's voice.

Commentaries discussed social issues in settlements, including the increase of population and law and order challenges. The commentaries looked at police programs addressing issues related to violence and drug abuse in settlements and schools (Police target settlements, 2019). Police persistently commented on the impact of overcrowding and lack of opportunities available to people in settlements, linking this to the escalating tensions in communities. As in the 'event' category, police again pointed out social issues and strongly recommended the government do something about the situation (Mushrooming settlements, 2019). Alex H Jafa, in The National's online section, also tried to highlight the larger structural issues that impact on people who live in settlements (Jafa, 2019). His article highlighted the lack of basic human rights and linked it into NCD's initiative to create affordable housing. At times, members of parliament demonstrated an understanding of the difficulties that communities in settlements face, and commented on possible solutions, as in the following reported remark by Port Moresby Northeast MP John Kaupa :

\begin{abstract}
'What we the leaders have to do is to provide opportunity for the people to get themselves engaged in some form of money-generating activities rather than illegal ways as they struggle to survive in the city'...He [Kaupa] said as the MP responsible for his electorate he has launched the small and medium enterprises program, provide seed capital to people to generate income. (Kil, 2019)
\end{abstract}

Kaupa went on to say people in settlements 'have talents, dreams to be somebody and they need an enabling factor to utilise these skills and talents to generate and income' (Kil, 2019). Rarely were community voices sought for their opinion. When they did get interviewed, however, they highlighted the challenges with government initiatives aimed at supporting and improving their lives. For example, Saun Dambui, a ward 8 councillor for Madang Urban and a community leader talked about the inadequacy of the COVID awareness protocols supported through the Madang provincial authorities:

'Most of the settlements in Madang Urban use drains or dug out wells
because they do not have access to clean running water...More needs to be
done so most settlements can have access to clean running water in order
for people to practice hand-washing.' (Dambui, 2020)

Individuals' voices were mostly captured under letters. These included commentaries that pointed towards certain needs in settlements and expressed negative 
sentiments with regards to the state and existence of settlements. Some, like Jennifer, gave scathing criticism, others understood that those living in settlements were faced with social and economic pressures that led to social unrest, and those who lived in settlements highlighted their difficulties.

A number of letters containing commentaries captured issues pertaining to settlements in the NCD. Phillzmon (2019) urged the government 'to find the root of the issues and problems that we face every day'. He talked about the growing issue of illegal squatter settlements, and urged the Member responsible to find ways to address the growing social and health concerns in the area. Others living near settlements shared their fear and frustrations resulting from experiences with crime (Bogosia, 2020). Savannah Heights, Waigani went so far as to say that most of the law and order issues are caused by those in the settlements, and that 'leaders should be brave enough to make tough decisions' to get rid of settlements (Wane, 2020). Ultange Wane said that 'eviction should be the only way after notices have been served' to resolve the increasing illegal settlement issues (Wane, 2020).

Words that describe settlements and the descriptions of settlements in the letters include '... breeding ground for criminal activities... an environment conducive for drug trade, especially marijuana. Illegal operation of liquor shops, gambling and prostitution is a common sight in settlements' (Igabi, 2020). In contrast, those who live in settlements presented the challenges they faced. For example, a resident of Morata Settlement raised the concern of water with his local MP, stressing the importance of access to water (Tange, 2020). Bruce, also from Morata, shared similar frustrations at the NCD's lack of attention to water supply (Bruce, 2020). Residents from the settlements acknowledge that life is hard, and that, and while they would like to enjoy the benefits of basic services and living well, those benefits remain out of their reach.

\section{Table 1: Sources quoted in the media $(\mathrm{N}=72)$}

Sources Quoted

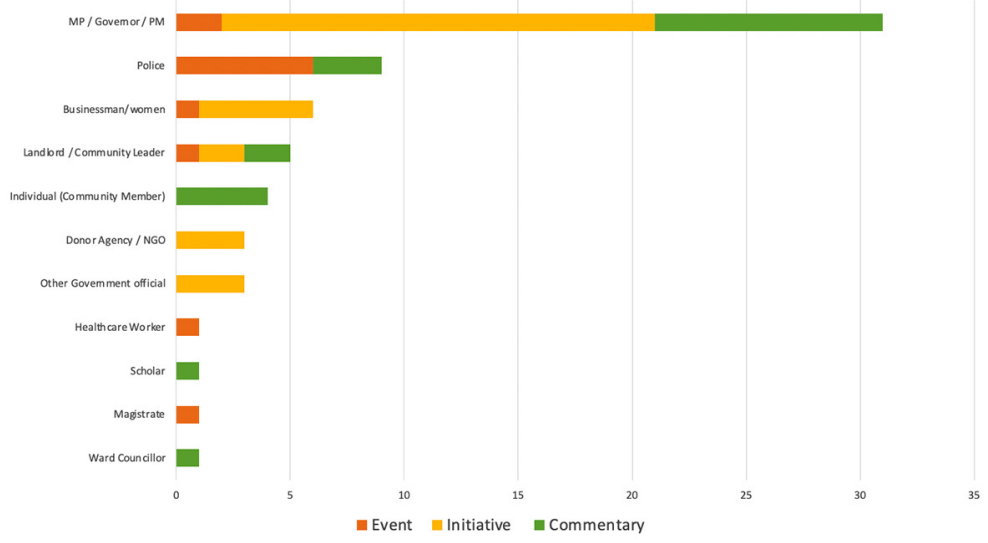




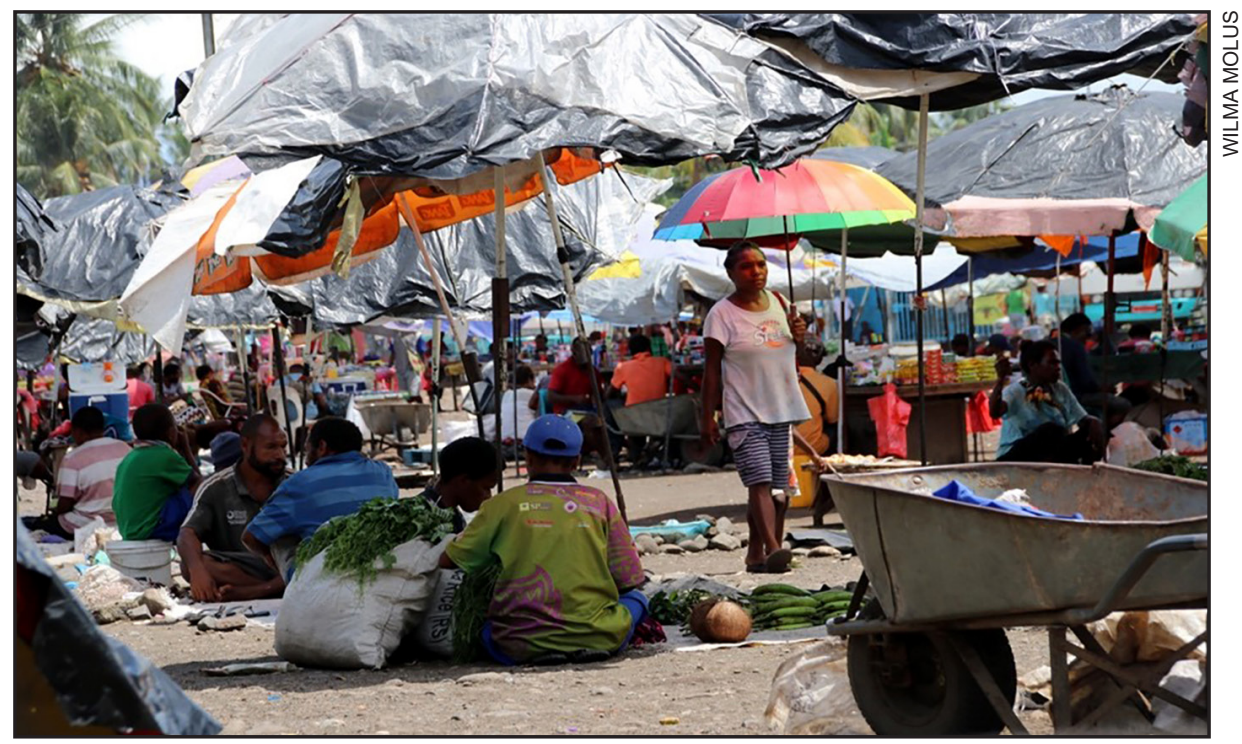

Figure 1: Awagasi Market in Lae City

Across the three categories of events, commentaries and initiatives, a key finding was that the most vocal personalities were from government and the police (see Figure 1). Significantly, community members' voices were minimally heard. In many cases, community members and leaders echoed their voices only behind government agents. Police were the most frequently quoted sources for accounts of events occurring within settlements, such as evictions and crimes, as these tended to be documented through media releases issues by the police.

The media analysis provided a background for the next phase of the study, which sought to capture the voices of people living in a settlement community - in this case, market vendors - to listen to their experiences and suggestions.

\section{Stories by Awagasi market vendors}

The study sought to capture residents' perspectives on their experiences of Kamkumung Settlement, with a particular focus on experiences of market vendors at Awagasi Market. The purpose of the storytelling and photovoice workshop was to explore participants' voices so as to understand the existing system and structures that support their livelihoods. Every individual had personal stories about various activities in life that improved their living standards at individual and family levels. The framing questions provided to participants were relevant to their everyday market experiences in regard to who they are, what they do, income-earning opportunities to support families, challenges faced by vendors, solutions to address those challenges, and how networks support each other.

Participants' engagement with the informal market space offered insights 
into their daily activities and strategies to maintain their livelihoods. Zaizozai shared his story:

My name is Zaizozai, I am married with 6 children. I am from Finchhafen in the Morobe Province. I live here in Awagasi, at Martha's block. At the market I help the bulk buai sellers to sell off their remaining buai. [...] The good thing is Awagasi Market provides a space for us to earn a living, it helps us to bring in K1, K2 to buy clothes and food for our homes, and food for our families. A lot of good things come from this market. I save money that I earn from the market for school fees for my children so they can go and get a good job.

Participants shared their various ways of generating income to support their living in the settlement. The Awagasi market is the economic hub of hundreds of settlers in Awagasi and Kamkumung settlements at large. The market provides members of the settlement the opportunity to conduct marketing activities to earn a daily income to meet their basic needs. Many participants also shared how they encouraged young people to engage in vending activities at the market to earn a living.

Challenges were experienced at various levels and due to various influences. Vendors face a number of hindrances that might jeopardise their vending endeavours. Difficulties described by workshop participants included bad weather, disturbances by intoxicated residents, high market competition, ethnic fights, and sale of fake or damaged items. Bad weather, especially rain, was one of the major factors mentioned that can cause havoc on the normal operation of the market. As A'ya'ewa shared:

When it rains, I don't get a profit as people don't come to buy things, and when this happens, I find it difficult to find food for the house for the evening food, so I have to borrow money or buy food on credit to feed my family. The next day, when the day clears, I sell my second-hand items and I pay off my credit. (A'ya'ewa, photovoice participant Mata Block, 2020)

A'ya'ewa's story demonstrates the pressure that many residents faced, relying on an income on a daily basis. Developing solutions to challenging situations, vendors and residents relied on others for assistance in overcoming those challenges. Bonny shared some of the challenges of resolving conflicts alongside his photo of his buai-table (Figure 2):

At the marketplace, we face challenges, drunkards come and disturb our marketing. This upsets me and I start arguing with them and a fight might erupt. The market council or the local police come and stop the argument and I often take the matter to the police station to be resolved. If the fight 


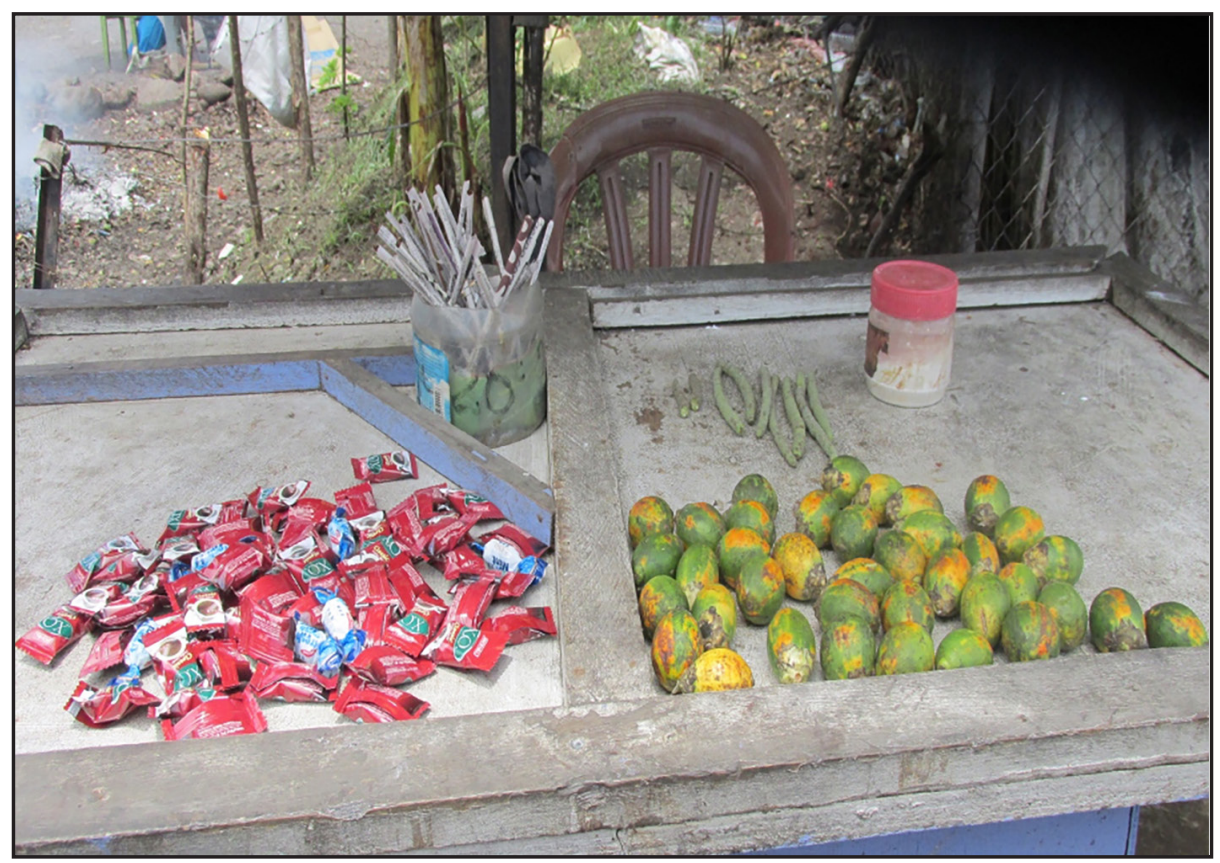

Figure 2: Bonny's buai-table at Awagasi Market, Lae.

gets bigger, the committee could shut the market down and this impacts our life. So, to maintain peace, we report the matter to the law, and they deal with it [...] Here at Awagasi, we come from many different provinces and other places, we help each other out with food and other things (Bonny, Photovoice Participant, Mata Block, 2020).

Participants acknowledged the issue of safety and disturbances at the market. They shared various strategies that they use to address safety and security issues. Vendors who hail from various ethnic groups build social networks within the market area and the settlement at large. Social capital works as an avenue whereby vendors establish rapport and connection with residents and other vendors, who would in turn help in many other areas, including providing security, assisting in lending things, and buying items.

Awagasi market also has established local mediation committees to deal with conflicts as they emerge. The mediation committee is made up of community leaders from various ethnic groups residing within Kamkumung settlement, who are appointed by the settlement populace and selected on the basis of cultural, social, economic and religious status. Women leaders within the committee are mostly landowners and church leaders. Any conflict that warrants police action is brought before the committee members. The usual meeting place is the Omili police station everyday Sunday; and the conflicting parties would return on a 
set date, and all issues are addressed in the presence of local police. The presence of Omili police station just meters away from the market, in addition to strong community leadership, ensures that criminal elements, offenders, fraudsters and other deviant characters are brought before the police and law and order committee.

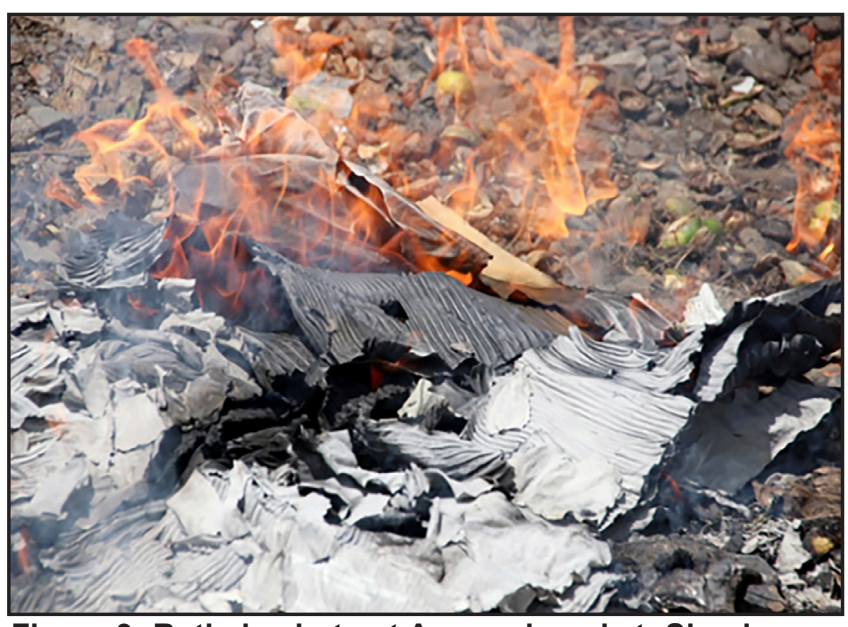

Figure 3: Ruthy's photo at Awagasi market: She dreams of buying her own block of land. One woman leader who was a workshop participant said: 'We usually go back and talk to the people from the market to behave properly and do market' (Photovoice Research Participant, Mata Block, 2020). The vendors, residents and customers are fully aware of the process of local conflict resolution methods, and workshop participants shared their individual experiences and hopes for a safe market space and community.

Most vendors further expressed their dreams of owning a portion of land within the settlement area and building houses to sell their local hand-crafted items. Some expressed their dream of owning a trade store, whilst a few expressed their dreams of owning cars and small shelters to sell hand-made items like string bags (bilums), artifacts and clothes. Ruth shared her dream (Figure 3):

\begin{abstract}
My name is Ruthy, I am from Finchafen, I stay at Awagasi, I am not married. I sell betelnut at Awagasi market. [...] Awagasi market has helped me a lot to buy my clothes and to help with my brother's kids. I want to save up and buy my own block of land, have my own area and so my brother's children can come and help me and also live with me.
\end{abstract}

Moreover, some expressed hopes of seeing their children succeed in schools and getting good jobs in the future. In the reflection session, vendors shared their views on the process of storytelling and photovoice, and how the processes helped them to develop their dreams: 'I learnt many things from this workshop. I learnt how to take care of ourselves, we learnt good things. And also, we learnt how to bring our dreams into reality' (Photovoice Participant, Mata Block, 2020). Residents working in their own community taking photos generated much interest from their community. One participant said: 'there are 
many that doubt us and our abilities, even within our own community. When our stories are out there, people can see our real experiences and that will help us'. The workshop generated a collective agency where vendors' voices were captured so they can be shared within and beyond their community.

\section{Discussion}

The media analysis demonstrated that residents' and community voices were mostly absent from the media representation. This could have contributed to the evident lack of empathy and depth in understanding the context and experiences of residents. Furthermore, residents were seldom credited in creating change and supporting initiatives. Instead, media reported on initiatives and interventions from the perspectives of government and police. As Scambary (2013) noted with regards to settlement communities, 'too narrow a focus on problems and their causes can ignore sources of community resilience-the community-driven creative responses and capacities for endurance to such difficult environments' (Scambary 2013, citing Brown 2007, p. 1936). In contrast to this, the storytelling and photovoice processes focused on residents' experiences. This process allowed an in-depth perspective on how residents themselves developed strategies to overcome challenges, as active contributors and decision-makers, which did not fully emerge from the representation in the media. In the following discussion, we contextualise these results further, firstly with regards to perspectives on journalism practices, and then in relation to opportunities for participatory processes in collaboration with settlement residents that might inform urban planning.

Proponents of critical development journalism in the Pacific (Robie, 2013, 2014; Sharp \& Papoutsaki, 2008) have over the past two decades outlined a need for journalists to report not only mere facts, but also the causes and processes leading up to events, including the questions of 'What, How and Why' (Robie, 2013, 2014). The approach aligns with the concept of 'deliberative journalism', which allows all relevant community stakeholders - including minorities, the marginalised, the disadvantaged, and even those deemed 'deviant' - to have their voices heard over an issue (Romano, 2010, p. 4). In a more recent analysis, Robie (2019) further argues that such an approach, which he terms 'talanoa journalism', needs to align with cultural perspectives and understandings, including the Pacific Way, in order to involve grassroots stakeholders, identify local solutions, and better understand and report on local contexts. While our media analysis identified many articles that were supportive of settlements and the development of settlements, the limited representation of community perspectives led to a limited acknowledgement of locally-developed solutions within settlement communities. In such representations, communities and their members remain passive players in the stories that affected their lives. 
In contrast, most recent research on settlement and urban markets has focused on understanding residents and market vendors' roles in decision-making processes and their active role in communities. According to the World Bank Group (2014), institutions like urban markets are frequently overlooked in the provision of government services because they exist outside of the official town planning areas, often on customary land, and so are institutionally 'orphaned'. However, market vendors, some of whom are community leaders, have been innovative and resilient in creating opportunities to address infrastructure and security issues and continue generating income despite limited government support. This is in line with a World Bank report containing an account of the role of community leaders in transforming one of Port Moresby's notorious and ethnically diverse markets and gaining its safety status. When the means by which the market achieved its safety status was explored, it was attributed to community leaders, rather than the formal law and order sector (Craig \& Porter, 2017). Similar strategies were documented by Awagasi market vendors, who described situations in which community leaders, in collaboration with landlords or as individuals, developed internal conflict-resolution strategies to address issues affecting both the market and settlement. However, such strategies were not reflected in the media coverage. In addition, as noted by Underhill-Sem, Cox, Lacey, and Szamier (2014), in the specific context of the market place, women vendors who are leaders are key market transformers and are willing to act on issues, negotiate and be responsible for distinct political and economic arrangements. In our analysis, women's voices were found to be significantly absent from media representation on settlements.

Urban settlement communities have a long history of marginalisation in PNG. Over the years, and today making up about half the population of urban centres, settlement communities are more diverse than ever, with blurred boundaries between informal and formal. Over time, with development and population boom in the cities, urban settlements have become genuine residences for a mix of different groups of people, including employees of both public and private sectors. Understanding these diverse perspectives might require a 'a more nuanced, reflexive approach to the craft and profession' (Robie 2019, p. 13), such as talanoa journalism or critical development journalism. And to some extent, the media's limitations in reporting fairly and responsibly may lie and be further considered within the domains of journalism education.

Meanwhile, the mainstream media's limitations in representing the voices of settlement residents might be partially covered by the development of social media and community media projects wherein voices of individuals can be heard. For example, realising the impact and importance of the news on social media, the National Capital District Youth Desk and Public Relations Department initiated a five-day training for settlement youth on how to use social media responsibly 
'so that their voices can be heard by those in authority' (Workshop helps settlement youth, 2019). Similar to the storytelling and photovoice workshop, such training and engagement opens up a space for people to narrate and create their own stories. Supporting such initiatives builds on local structures and contexts.

\section{Conclusion}

In this article we have discussed the representation of settlement communities in PNG through online media representation and through personal stories from market vendors in Kamkumung Settlement Lae. We have highlighted the need for increased representation of voices of residents to be reflected in the media. We have argued that, by better understanding the context and personal experience of residents, journalists and the media could make a stronger contribution to sustainable development and urban planning in PNG, as well as to improving general understanding of the root causes of issues experienced. Demonstrated by research conducted in urban settlements, local solutions are key in creating sustainable solutions for settlement communities. Taking this on board, the media can, if taking a critical development journalism approach, play an important role in supporting settlement communities. Such an approach might feature more strongly in education and training of journalists in the Pacific, in order that they may advocate for those who are underrepresented in the mainstream media.

The study was limited in that it did not involve speaking with journalists, and limited its scope to online searches. Further research could include the involvement of journalists to obtain their perspectives. Collaborative workshops might provide further insights into the different perspectives. This article can inform the further development of such community-based interventions, in order to strengthen settlement residents' voices. For the Kamkumung community, their next step is the organisation of an exhibition to share their stories. It is their hope that those in decision-making positions, and the media, can attend their exhibition and see and hear their stories.

\section{References}

Bogosia, S. (2020). Call to remove settlement. The National. Retrieved September 2, 2021, from https://www.thenational.com.pg/call-to-remove-settlement

Bruce (2020). One thought on 'settlement needs water supply'. The National. Retrieved on September 2, 2021, from https://www.thenational.com.pg/settlement-needswater-supply/

City authorities clamp down on illegal settlement (2020a, August 31). The National. Retrieved September 2, 2021, from https://www.thenational.com.pg/city-authoritiesclamp-down-on-illegal-settlement/

Cops: Remove settlements. (2021a, March 4). The National Newspaper. Retrieved September 2, 2021, from https://www.thenational.com.pg/cops-remove-settlements/ Craig, D., \& Porter, D. (2017). 'There is security from this place': Promoting the safety 
and economic vitality of Port Moresby's local markets. World Bank, Washington, DC. Retrieved on September 2, 2021, from https://openknowledge.worldbank.org/ handle/10986/26380

Dambui, S. (2020). No clean water in Madang. EMTV. Retrieved from https://evtv.com. $\mathrm{pg} /$ no-clean-water-in-madang-settlements

Get rid of settlements (2021b, April 26). The National. Retrieved September 2, 2021, from https://www.thenational.com.pg/get-rid-of-settlements-2/

Goddard, M. (2001). From rolling thunder to reggae: Imagining squatter settlements in Papua New Guinea. The Contemporary Pacific, 13(1), 1-32. https://doi.org/10.1353/ cp.2001.0007

Igabi, M. (2020, April 4). Address issues with settlements. The National. Retrieved September 2, 2021, from https://www.thenational.com.pg/address-issues-withsettlements/

Jafa, A. H. (2019, July 4). Upgrading settlements. The National. Retrieved September 2, 2021, from http://www.thenational.com.pg/upgrading-settlements/

Jones, P. (2012). Pacific urbanisation and the rise of informal settlements: Trends and implications from Port Moresby. Urban Policy and Research, 30(2), 145-160. https:// doi.org/10.1080/08111146.2012.664930

Keneqa, L. (2020). Water Supply Connected to 2 Mile Hill settlement. EM-TV. Retrieved September 2, 2021, from https://emtv.com.pg/water-supply-connected-to-2-milehill-settlement/

Kep, Y. (2019, April 25). Port Moresby settlements to receive mosquitoe nets. PNG Post-Courier. Retrieved September 2, 2021, from https://postcourier.com.pg/portmoresby-settlements-receive-mosquito-nets/

Kil, L. (2019, October 3). Overcrowding in settlements an obstacle to maintaining law and order: Kaupa. PNG Post-Courier. Retrieved September 2, 2021, from https://postcourier. com.pg/overcrowding-in-settlements-an-obstacle-to-maintaining-law-and-order-kaupa/

Koczberski, G., \& Curry, G. N. (2005). Making a living: Land pressures and changing livelihood strategies among oil palm settlers in Papua New Guinea. Agricultural Systems, 85(3), 324-339.

Koczberski, G., Curry, G. N., \& Connell, J. (2001). Full circle or spiralling out of control? State violence and the control of urbanisation in Papua New Guinea. Urban Studies, 38(11), 2017-2036.

Kopel, E., Hukula, F., Kutan, L., \& Iwong, L. (2017). Understanding gender dynamics of the informal economy: The case of open markets in Port Moresby. Retrieved September 2, 2021, from https://pngnri.org/images/Publications/Understandinggender-dynamics-of-the-informal-economy-Nov2017-copy.pdf

Mecartney, S., \& Connell, J. (2017). Urban Melanesia: The challenges of managing land, modernity and tradition. In S. McDonnell, M. G. Allen, \& C. Filer (Eds.), Kastom, property and ideology (pp. 57-84). Canberra, ACT: ANU Press.

Moresby South MP moves to ban alcohol in settlements. (2020, January 18). PNG Post-Courier. Retrieved September 2, 2021, from http://postcourier.com.pg/moresbysouth-mp-moves-to-ban-alcohol-in-settlement

Mushrooming settlements, ignorance of regulations pose a serious law and order challenge. (2019, October 1). PNG Post-Courier. Retrieved September 2, 2021, from http://postcourier.com.pg/mushrooming-settlements-ignorance-of-regulations-posea-serious-law-and-order-challenge- $2 /$

Musoke, D., Ekirapa-Kiracho, E., Ndejjo, R., \& George, A. (2015). Using photovoice to examine community level barriers affecting maternal health in rural Wakiso district, 
Uganda. Reproductive Health Matters, 23(45), 136-147. https://doi.org/10.1016/j. rhm.2015.06.011

Nagada settlement eviction begins: Kramer (2021c, January 22) The National. Retrieved September 2, 2021, from http://www.thenational.com.pg/nagada-settlement-evictionbegins-kramer

Nao, K. (2020, May 20). Hearty meals for days at Siraka settlement. PNG Post-Courier. Retrieved September 2, 2021, from http://postcourier.com.pg/hearty-meals-for-daysat-siraka-settlement

Nagada settlement eviction begins: Kramer (2021c, January 22) The National. Retrieved September 2, 2021, from http://www.thenational.com.pg/nagada-settlement-evictionbegins-kramer

Numbasa, G., \& Koczberski, G. (2012). Migration, informal urban settlements and nonmarket land transactions: a case study of Wewak, East Sepik Province, Papua New Guinea. Australian Geographer, 43(2), 143-161.

One dead, several homes torched after ethnic clash erupts in city settlements (2021, March 4) PNG-Post Courier. Retrieved September 2, 2021, from https://postcourier. com.pg/one-dead-several-homes-torched-after-ethnic-clash-erupts-in-city-settlement/

Phillzmon, B. (2019). Squatter Settlement. The National. Retrieved September 2, 2021, from https://www.thenational.com.pg/squatter-settlement

PNG citizen perceptions of governance and media engagement report (2019). Port Moresby, PNG: ABC International Development.

Police destroyed makeshift houses in settlement. (2020b, January 24). The National. Retrieved September 2, 2021, from http://www.thenational.com.pg/police-destroymakeshift-houses-in-settlement

Police target settlements in war on drugs and violence. (2019, March 29). The National. Retrieved September 2, 2021, from https://www.thenational.com.pg/police-targetsettlements-in-war-on-drugs-and-violence/

Robie, D. (2013). 'Four Worlds' news values revisited: A deliberative journalism paradigm for Pacific media. Pacific Journalism Review : PJR, 19(1), 84-110. doi:10.24135/pjr. v19i1.240

Robie, D. (2014). Don't spoil my beautiful face: Media mayhem and human rights in the Pacific. Auckland, NZ: Little Island Press.

Robie, D. (2019). Karoronga, kele'a, talanoa, tapoetethakot and va: expanding millennial notions of a 'Pacific way' journalism education and media research culture. Media Asia, 46(1-2), 1-17. https://doi.org/10.1080/01296612.2019.1601409

Romano, A. (2010). International journalism and democracy civic engagement models from around the world (First edition). New York, NY : Routledge.

Rooney, M. N. (2019). Sharing what can be sold: Women haus maket vendors in Port Moresby's settlements. Oceania, 89(2), 154-167. https://doi.org/10.1002/ocea.5217

Saraga settlement to suburb project launched. (2021, January 26). PNG Loop. Retrieved from https://www.looppng.com/png-news/saraga-settlement-suburb-projectlaunched-97142

Scambary, J. (2013). Conflict and resilience in an urban squatter settlement in Dili, East Timor. Urban Studies, 50(10), 1935-1950. https://doi.org/10.1177/0042098012470396

Sharp, S., \& Papoutsaki, E. (2008). Two models for Pacific islands journalism education. In Papoutsaki, E., \& Harris, U. S. (Eds.), South Pacific island communications: Regional perspectives, local issues (pp. 82-101). Singapore \& Auckland, NZ: Asian Media Information and Communication Centre (AMIC) and the Pacific Media Centre. Tacchi, J., Horst, H., Papoutsaki, E., Thomas, V., \& Eggins, J. (2013). PACMAS: State 
of media and communication report 2013. Melbourne, VIC: ABC International Development.

Tange, U. 1. (2020, June 9). Settlement needs water supply. The National. Retrieved from https://www.thenation.com.pg/settlement-needs-water

Underhill-Sem, Y., Cox, E., Lacey, A., \& Szamier, M. (2014). Changing market culture in the Pacific: Assembling a conceptual framework from diverse knowledge and experiences: Changing market culture in the Pacific. Asia Pacific Viewpoint, 55(3), 306-318. https://doi.org/ 10.1111/apv.12063

Wane, U. (2020, 11 March). Get rid of settlements. The National. Retrieved from https:// www.thnational.com.pg/get-rid-of-settlements

Wang, C. C., Yi, W. K., Tao, Z. W., \& Carovano, K. (1998). Photovoice as a Participatory Health Promotion Strategy. Health promotion international, 13(1), 75-86. https://doi. org/10.1093/heapro/13.1.75

World Bank Group. (2014). Papua New Guinea : Sanitation, water supply and hygiene in urban informal settlements. Washington, DC: World Bank.

Workshop helps settlement youths understand social media (2019). The National. Retrieved September 2, 2021, from https://www.thenational.com.pg/workshop-helpssettlement-youths-understand-social-media/

Wilma Molus is a PhD candidate with the Faculty of Creative Industries, Education and Social Justice at Queensland University of Technology. She is also a lecturer at the Papua New Guinea University of Technology. Her research focuses on urban settlements in Papua New Guinea and how urban economies promote relational governance and security systems in the urban market environment. wmolus@gmail.com

Verena Thomas is an associate professor in the Faculty of Creative Industries, Education and Social Justice at Queensland University of Technology. Her research focuses on communication and social change, communication for development, arts-based research, and visual methodologies. verena.thomas@qut.edu.au

Jackie Kauli is an associate professor in the Faculty of Creative Industries, Education and Social Justice at Queensland University of Technology. Her work is in the area of drama and applied theatre and its utility in understanding and addressing social issues. She works across Papua New Guinea and Australia. j.kauli@qut.edu.au

Laurie Buys, PhD, is professor and director of the Healthy Ageing Initiative at the University of Queensland. She is an experienced social science researcher and research manager, who frequently collaborates with scientists from various disciplinary backgrounds on complex research initiatives. L.buys@uq.edu.au 